\title{
EFFECT OF AGE OF COCKERELS ON THE TRANQUILIZING EFFICACY OF DIAZEPAM
}

\author{
J. ŠIMƯNEK, E. HEGEROVÁ, R. ZAVADILOVÁ and J. KLIMEŠOVÁ
}

Department of Pharmacology and Toxicology, University of Veterinary Science, 61242 Brno

Received Fanuary 18, 1980

\begin{abstract}
Šimůnek J., E. Hegerová, R. Zavadilová and J. Klimešová: Effect of Age of Cockerels on the Tranquilizing Efficacy of Diazepam. Acta vet. Brno, 50, 1981: 49-52.

In experiments involving cockerels of various ages the tranquilizing efficacy of diazepam was studied by means of clinically detectable changes in selected reflexes and behaviour of the birds. Czechoslovak newly developed suspensions of diazepam made by the Research Institute of Pharmacy and Biochemistry (Prague) and by the Research Institute of Feed Supplements and Veterinary Drugs (Jilové near Prague) were used in the study.

The tranquilizing efficacy of diazepam was shown to be dose-dependent and it decreased with ageing of the birds as demonstrated in the experiment on 2-, 5- and 8 -week old cockerels given 10 and $30 \mathrm{mg} / \mathrm{kg}$ live body mass into the crop. In the second experiment on 2-, 9- and 42-day old birds treated with 15,50 and $300 \mathrm{mg} / \mathrm{kg}$ dependence of diazepam efficacy on its dose and age of the birds was demonstrated, too.

The results yielded unequivocal evidence of different sensitivity of cockerels of various ages to the tranquilizing effect of diazepam. They further indicate the possible use of clinical parameters expressed as quantitative indicators for graphic presentation when evaluating efficacy of ataractics.
\end{abstract}

Diazepam, age, graphic presentation, tranquilization.

Previous experiments have shown that the effects of drugs in animals of various ages differ widely in efficacy or reverse course of changes in effect and toxicity may occur (Ši im ůnek 1974). The effects of drugs of various pharmacological groups change depending upon age and can also differ from species to species.

At present, of increased importance seems to be the use of psychosedative drugs not only for individual treatment but also for mass treatment in large-scale animal production. With modern technologies heavy stress situations occur which always have a negative impact on animal productivity. For protection of animals against these negative effects psychosedative drugs proved to be useful. The tranquilizing effect of the more potent drugs of this group (neuroleptics) is often too strong for use in practice. Therefore attention has been also paid to less potent substances (ataractics). For large-scale use a new substance, product of Czechoslovak pharmaceutical industry, Diazepam susp. ad usum vet. has been developed.

Diazepam has a typical tranquilizing effect on the CNS. As with other substances acting predominantly in the CNS, e. g. convulsive drugs and their antidotes, species differences also occur with diazepam (Chin et al. 1978). Many authors appreciate the ataractic, myorelaxant and body mass increase-promoting effects of diazepam in pigs (Kania 1975; Dantzer 1977; Fitko and Kordzielewski 1977). Oral administration of the drug proved advantageous in pigs and poultry while the i. $\mathrm{m}$. route was found more suitable in ruminants and horses (Drumev et al. 1972). Efficacy of diazepam is also dependent upon its form and route of administration (Viala and Cano 1969; Jeppson and Ljundberg 1975; Hillestad et al. 1974). Fendrich et al. (1976) found that diazepam is absorbed by passive diffusion from the intestine so that the mucosal surface and its state may greatly affect diazepam absorption.

In adult humans extensive metabolic degradation of diazepam was found with biological half- 
-life of 24 hours whereas in the newborn it was 35 hours, probably due to differences in hydroxilation capacity (Morselli 1974).

Experiments studying the effects of psychosedative drugs in animals present several problems of methodical character. Currently the anticonvulsive effects of these substances in the anti-pentylenetetrazol test are followed (Květina 1975). Further evaluation of this interaction can be based on measurements of the acute toxicity of the convulsive drug. In another work ( $\mathrm{imu}$ u nek et al. 1980) we used the effect of diazepam on the $\mathrm{LD}_{50}$ of pentylenetetratol as a criterion of this interaction. However, the clinical assesment of psychosedative effects on the animal body still remains questionable. In the present work an attempt is made to give a graphic presentation of the results based on assessment of changes in several selected clinically detectable parameters.

\section{Materials and Methods}

For the experiments sexed cockerels aged 2 days to 8 weeks were employed. For treatment diazepam suspensions were used made by the Research Institute of Pharmacy and Biochemistry (VÚFB), Prague (experiment 1), and by the Research Institute of Feed Supplements and Veterinary Drugs (VÚBVL), Jílové near Prague (experiment 2).

In experiment 1, groups of 6 cockerels aged 2, 5 and 8 weeks were used. The birds were given diazepam indivudually into the crop at the dose of 10 and $30 \mathrm{mg} / \mathrm{kg}$ live body mass.

In experiment 2, groups of 10 cockerels aged 2, 9 and 42 days were used. The birds were treated in the same way with doses being 15,30 and $300 \mathrm{mg} / \mathrm{kg}$ diazepam.

The effects of diazepam were evaluated according to changes in selected reflexes and/or behaviour. As the parameters followed in both experiments did not correspond exactly, for graphic presentation only those comparable in both trials were used, namely, somnolence, apathy, food intake pattern and a complex of reactions to handling. The sum of these parameters was expressed as 100 per cent. The results were plotted in graph with ordinate indicating percentage of diazepam efficacy according to the selected criteria and abscissa indicating observation times. In the first experiment the observations were not done at the same time for all groups so that only comparable observation sessions were used.

\section{Results and Discussion}

Results of both experiments are given in Fig. 1 and Fig. 2. In the selected interpretation these data demonstrate clearly the tranquilizing effect of diazepam in cockerels. Both experiments have shown that the age of birds affects diazepam efficacy in the same way: with ageing diazepam efficacy decreases. From this point of view the identical efficacy of the both higher doses in two-day old birds and

age of chickens
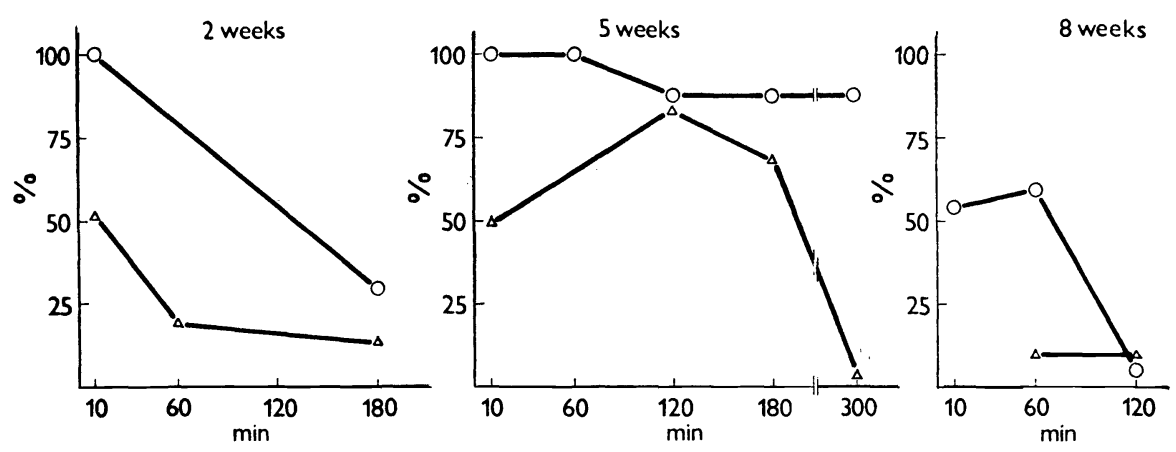

Fig. 1

Total sedative effect expressed in per cent (maximum sedation $=100 \%$ ) in chickens of various ages given a single dose of diazepam suspension into the crop. Active substance concentrations: $10 \mathrm{mg} / \mathrm{kg}(\triangle), 30 \mathrm{mg} / \mathrm{kg}(\mathrm{O})$ live body mass. 
a very close efficacy at the lowest dose is remarkable. This phenomenon, as well as differring effects of diazepam in the age groups under study can in our opinion be ascribed to differences in its kinetics and differences in CNS maturation depending on the ontogenic development of the animals.

Considering the fact that precocial birds at hatching are relatively more mature than newborn mammals, our finding of considerable age differences in diazepam efficacy in chickens is rather remarkable.

age of chickens
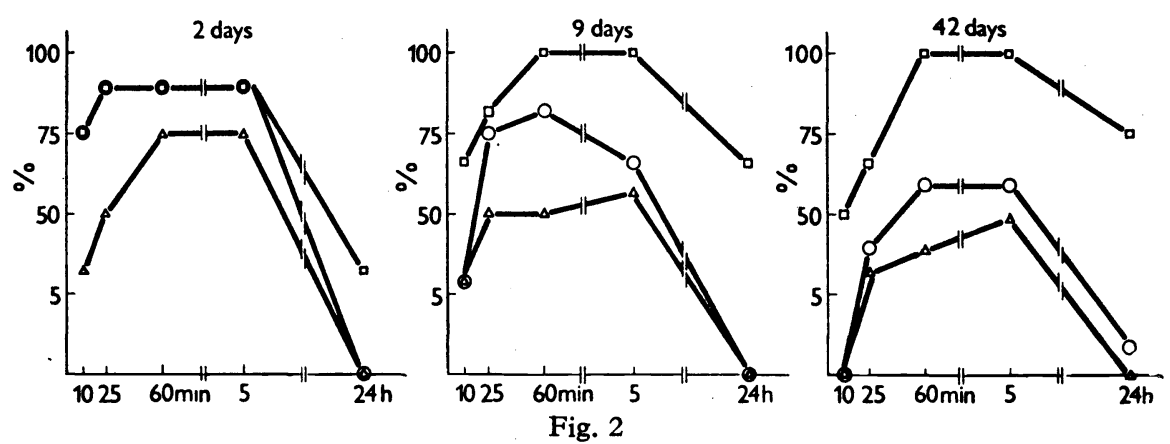

Total sedative effect expressed in per cent (maximum sedaticn $=100 \%$ ) in chickens of various ages given a single dose of diazepam suspension into the crop. Active substance concentrations: $15 \mathrm{mg} / \mathrm{kg}(\triangle), 50 \mathrm{mg} / \mathrm{kg}(\mathrm{O}), 300 \mathrm{mg} / \mathrm{kg}([;)$ live body mass.

Presented form of diazepam efficacy assay based on numerical transfer of clinical criteria (changes in selected reflexes an behaviour) can be considered as a successful evaluation of the drug's effects on chickens. In our opinion, it is worthwhile to continue along this line and to further refine the criteria as to their number, selection and importance. It is obvious that this way of expressing the diazepam efficacy contains a certain error in that not all parameters are of equal value. Nevertheless, even employing these criteria with animals under study, only a relative comparison is made in which case the error is negligible.

An exact comparison of our results is not possible as the age of birds in the two experiments differed. Despite these partly small differences it is not appropriate to compare the data directly as our previous studies have shown the influence of developmental changes on the efficacy of drugs (Šimůnek 1974). It is therefore obvious that especially in domestic fowl aged less than 8 weeks differences of few days can make themselves felt considerably. Further neither diazepam doses nor its provenience were identical in the two trials. Nevertheless, even under these conditions it is evident that the tranquilizing effect of diazepam was less pronounced in older birds.

\section{Vliv věku kohoutků na zklidňující účinek diazepamu}

V pokusech na rozdílně starých skupinách kura domácího byl pomocí klinicky zjistitelných změn vybraných reflexů a chování zvířat hodnocen tlumivý účinek diazepamu v čs. vývojových suspensích VÚFB a VÚBVL. Výsledky jsou znázorněny graficky. $V$ pokuse $s$ kohoutky starými 2,5 a 8 týdnů, kterým byl podán do volete diazepam v dávce 10 a $30 \mathrm{mg} / \mathrm{kg}$ ž. h. se ukázalo, že tlumivý účinek je zá- 
vislý na dávce a že se $\mathrm{v}$ závislosti na věku jeho intenzita snižuje. $\mathrm{V}$ pokuse $\mathrm{s}$ kohoutky starými 2, 9 a 41 dnů, kterým byl podán do volete diazepam v dávce 15, 50 a $300 \mathrm{mg} / \mathrm{kg}$ ž. h. se závislost účinku na dávce a věku projevila shodně.

Pokusy jednoznačně prokázaly rozdílnou citlivost kohoutků různého věku na tlumivé působení diazepamu. Pokusy dále naznačují možnost použít při hodnocení ataraktik mj. i klinicky sledovaných ukazatelů převedených na kvantitativní ukazatele pro grafické znázornění.

\section{Влияние века на эфективность тиазепама у петушков}

В ходе опытов с курицами разных возрастных групп с помощью клинически выявляемых изменений избранных рефлексов и поведений животных проводилась оценка тормозящего воздействия диазепама в чехословацких опытных суспензиях VÜFB и VÜBVL. Результаты изображены графически. В ходе опытов с петушками в возрасте 2,5 и 8 недель, которым в зоб вводилась доза диазепама 10 и $30 \mathrm{Mr} /$ кг живого веса, стало явным, что тормозящее воздействие зависит от дозы и что в зависимости от возраста его интенсивность понижается. В опытах с петушками в возрасте 2, 9 и 42 дня, которым в зоб вводилась доза диазепама 15, 50 и 300 мг/кг живого веса, зависимость воздействия от дозы и возраста проявилась тождественно.

Опыты доказали убедительно разную чувствительность петушков разного возраста к тормозящему воздействию диазепама. Опыты далее намечают возможность использовать в ходе оценки успокаивающих медикаментов помимо прочего также клинически исследуемых показателей, преобразованных в количественные показатели с целью графического изображения.

\section{References}

CHIN, L. - SIEVERS, M. L. - LAIRD, H. E. - HERRIER, R. N. - PICCHIONI, A. L.: Evaluation of diazepam and pyridoxine as antidotes to isoniazid intoxication in rats and dogs. Toxicol. appl. Pharmacol., 45, 1978: 713-722.

DANTZER, R.: Étude des effets du diazépam sur le compartement d'évitement continu chez le porc. J. Pharmacol. (Paris) 8, 1977: 415-426.

DRUMEW, D. - GEORGIEW, B. - KOITSCHEW, K. - DILOW, P. - MENDOW, C.: Die Wirkung von Diazepam (Faustan) bei landwirtschaftlichen Nutztieren. Mh. Vet. Med. 27, 1972: 615-621.

FENDRICH, Z. - KVĚTINA, J. - LÁZNÍČEK, M. - HRADIL, J.: Kinetika absorpce diazepamu a PABA z GIT u krys. Čs. fyziol. 25, 1976: 249.

FITKO, R. - KORDZIELEWSKI, K.: Przydatność Relanimalu i Anironu i prosiąt w zapobieganiu następstwom stressu adaptacyinego. Nowośći wet. 7, 1977: 27-30.

HILLESTADT, L. - HANSEN, T. - MELSOM, H.: Diazepam metabolism in normal man. I. Serum concentrations and clinical effects after intravenous, intramuscular, and oral administration. Clin. Pharmacol. Therap. 16, 1974: 479-484.

JEPPSSON, R. - LJUNGBERG, S.: Anticonvulsant activity in mice of diazepam in an emulsion formulation for intravenous administration. Acta pharmacol. toxicol. 36, 1975: 312-320.

KANIA, B. F. - SIWECKI, J. - SOBCZYK, J. - SIWEK, Z.: Przeciwstressowe działanie relanium (Diazepam) u świń. Medycyna Wet. 31, 1975: 680-683.

KVĚTINA, J.: Mezidruhové srovnávací a patofyziologické aspekty ve farmakologii. Univ. Karlova Praha $1975,285 \mathrm{pp}$.

MORSELLI, P. L.: Drug disposition during development. Acta Pharmac. Suecica 11, 1974: $645-652$.

SIMƯNEK, J.: Problematika dosologie léčiv v souvislosti s ontogenetickými změnami u zviŕat zejména se zřetelem $k$ sulfonamidům. DrSc. Thesis, VŠV Brno 1974, 240 pp.

ŠIMƯNEK, J. - HEGEROVÁ, E. - ŠVEC, J.: Studium interakce diazepamu a sulfadimidinu u tři věkových skupin kura dom. Biol.-chem.-Vet. $16(20), 1980: 369-374$.

VIALA, A. - CANO, J. P.: Teneurs sanguines en diazépam (Valium N. D.) après administration du médicament sous forme de gouttes ou de sirop. Thérapie 24, 1969: 1115-1121. 